\title{
Business Model Elements for Industrialised Building System
}

\author{
Mohamed Rizal Mohamed, Mohammad Fadhil Mohammad, Rohana \\ Mahbub
}

To Link this Article: http://dx.doi.org/10.6007/IJARBSS/v11-i4/9687

DOI:10.6007/IJARBSS/v11-i4/9687

Received: 14 February 2021, Revised: 16 March 2021, Accepted: 30 March 2021

Published Online: 20 April 2021

In-Text Citation: (Mohamed et al., 2021)

To Cite this Article: Mohamed, M. R., Mohammad, M. F., \& Mahbub, R. (2021). Business Model Elements for Industrialised Building System. International Journal of Academic Research in Business and Social Sciences, 10(4), 429-446.

\section{Copyright: (c) 2021 The Author(s)}

Published by Human Resource Management Academic Research Society (www.hrmars.com)

This article is published under the Creative Commons Attribution (CC BY 4.0) license. Anyone may reproduce, distribute, translate and create derivative works of this article (for both commercial and non-commercial purposes), subject to full attribution to the original publication and authors. The full terms of this license may be seen at: http://creativecommons.org/licences/by/4.0/legalcode

Vol. 11, No. 4, 2021, Pg. 429 - 446

Full Terms \& Conditions of access and use can be found at http://hrmars.com/index.php/pages/detail/publication-ethics 


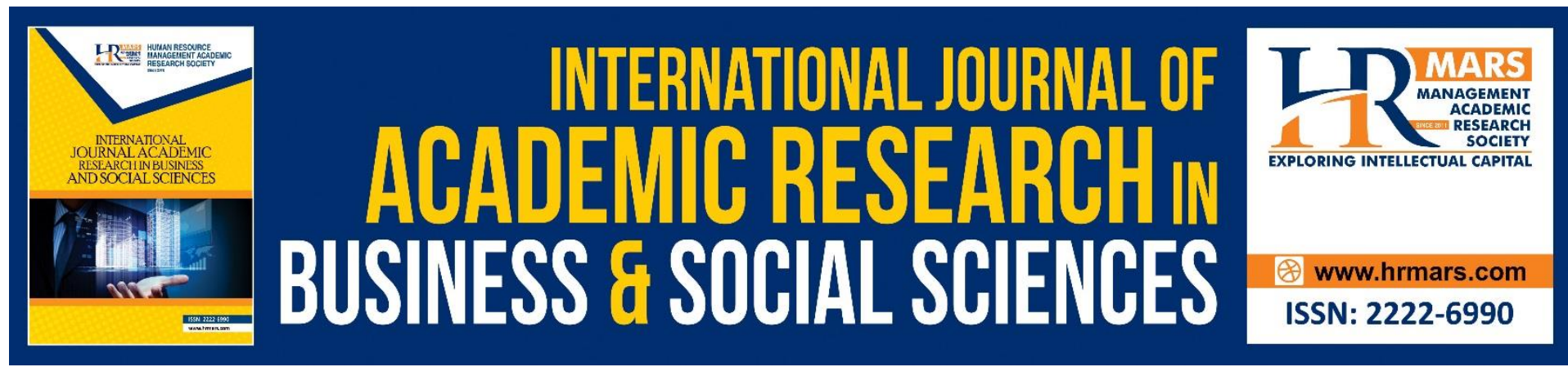

\title{
Business Model Elements for Industrialised Building System
}

\section{Mohamed Rizal Mohamed¹, Mohammad Fadhil Mohammad², Rohana Mahbub ${ }^{3}$}

'School of Architecture, Building and Design, Faculty of Innovation and Technology, Taylor's University, Malaysia, ${ }^{2}{ }^{3}$ Centre of Studies for Quantity Surveying, Faculty of Architecture, Planning and Surveying, Universiti Teknologi MARA, Malaysia

Email: rizal.mohamed@gmail.com

\begin{abstract}
The objective of this paper is to identify the elements of a viable business model that is suitable to be used by SME contractors in adopting Industrialised Building System (IBS). In order to achieve the objective this paper identifies and reviews the elements of business model that are important in business. A thorough review of the relevant literature on business model within the scope of IBS and supported by other industries had been conducted. From the findings, nineteen business model elements have been identified. There are 1. Target Customers, 2. Market Segments, 3. Marketing Strategy, 4. Distribution Channel, 5. Role in Supply Chain, 6. Supplier Relationship, 7. Product, 8. Design, 9. Manufacturing, 10. Installation, 11. Standardisation, 12. Customisation, 13. Production Method, 14. Key Resources, 15. Core Competencies, 16. Supply Chain Management, 17. Continuous Improvement, 18. Sales Management, and 19. Partnering. The finding is useful to SME contractors in guiding the SME contractors to move from conventional construction method to IBS practice and to increase their performance in IBS business. Future studies should make a quantitative ranking of the business model elements and analyses their relationship with IBS business performance.
\end{abstract}

Keywords: Industrialised Building System (IBS), Business Model Element, Construction Business, Small And Medium-Sized Contractor, Performance

\section{Introduction}

Active construction organisations, efficient construction processes and innovative construction techniques are required by the construction industry (Rashid, Abdullah, \& Ismail, 2019). Industrialised Building System (IBS) is seen as a suitable construction technique to be used to fulfill the requirement. IBS can be defined as a construction technique in which the building components are produced (on or off site) in a regulated setting, distributed, placed and assembled into a structure with minimal additional site work (CIBD, 2003). The term is used by the Malaysian construction industry and government to represent the prefabrication of building components in Malaysia (Kamar et al., 2012). Meanwhile in other countries, IBS is known as modern method of construction (MMC), off-site construction, off-site fabrication, 
off-site production, preassembly, off-site manufacturing, prefabrication, non-traditional building, industrialized building and system building (Brege et al., 2014; Goodier \& Gibb, 2007; Pan, 2006; Thuesen \& Hvam, 2013). IBS can be classified into six main categories which are; pre-cast concrete system, steel framing system, timber framing system, block work system, formwork system, and innovative system (CIDB, 2016; Din et al., 2012). There are many advantages of using IBS reported by researchers worldwide (Alinaitwe et al., 2006; Bhattacharjee et al., 2016; Blismas et al., 2006; Gibb \& Isack, 2003; Goodier \& Gibb, 2007; Hanafi et al., 2015; Haron et al., 2009; Hung et al., 2015; Jabar et al., 2013; Lou \& Kamar, 2012; Majid et al., 2011; Na \& Roger, 2008; Polat, 2008; Samari et al., 2012; Zhang et al., 2018). These advantages are more significant for adopters in terms of cost and time certainty, improving building efficiency and productivity, reducing workplace safety and health hazards, alleviating skilled workers' issues and reliance on manual foreign labour, and achieving the ultimate goal of reducing overall construction costs.

The government has been vigorously championing the use of this construction technique in public and private projects because of the benefits (Theong et al., 2018; Zakaria \& El-Abidi, 2020). In 2008, all government projects were made compulsory to use IBS where a minimum of 70 IBS score must be achieved for projects worth RM10 million and above as indicated in the Treasury Circular SPP 07/2008 and construction players are encouraged to use IBS for private projects where contractors who have achieved 50 IBS score for residential are exempted from the Malaysian construction levy (Hamid et al. 2008). Even though the initiative of promoting the adoption of IBS in the construction industry has been long implemented the participation of contractors in IBS business is still low especially among the Small and Medium-sized (SME) contractors (CIDB, 2015; Mohamed et al., 2018). The main reason for the low participation is due to the fact that many contractors are unlikely to accept the IBS construction and prefer to continue to use the conventional method of construction. This is because they are all too familiar with the conventional method of construction and the technology serves them well in their projects and are thus not prepared to move to a mechanised system (Mohamad et al., 2009; Zakaria et al., 2017). According to Mohamad et al. (2016), contractors who have adopted IBS projects were reluctant to use IBS in their next project. Hung et al. (2015) also mentioned that occasionally, contractors using IBS have shown non-satisfactory results. Furthermore, some were more costly, lack in quality and less productive. In some cases, selected building projects were conferred and built using IBS construction but ended up with project deferrals and low quality (Kasim et al., 2019; Rashid et al., 2019).

Goulding et al. (2015) opined that the low adoption and performace of IBS may, to an extent, be linked to the lack of preparation by contractors in terms of important modifications in their business model. A study conducted by Zairul (2020) found that in the Malaysian context, there is limited research on proposing ground-breaking business models for IBS. In order to survive and sustain their business in the construction industry SME contractors is suggested to become IBS contractors and adopt IBS in their construction business (CIDB, 2015; Mohamed et al., 2019; Theong et al., 2018). With the move to industrialize the construction sector, SME contractors will have to establish more innovative business models and plans for turnover growth (Goh \& Loosemore, 2017). SME contractors will require a specific business model to guide them in adopting the IBS construction (Mohamed et al. 2018). This is due to IBS being considered a specialised trade $(C I D B, 2015)$ and its construction approach is different from 
conventional construction method (Nawi et al., 2014). According to Mohamed et al. (2018), some SME contractors have little knowledge and experience in this modern method of construction. They are newly admitted contractors who wish to start a business in IBS. Due to this problem there is a need to thoroughly examine the role of business model in SME contractors business. SME contractors will require a specific business model to guide them in the IBS business. Thus, the objective of this paper is to identify the element of a viable business model that is suitable to be used by SME contractors in adopting IBS in their construction business. The business model elements can be used to guide the SME contractors to move from conventional construction method to IBS practice and to increase their performance in IBS business.

\section{Methodology}

This paper identifies and reviews the elements of a business model that are important in IBS business. The methodology adopted is primarily based on a thorough review of the relevant literature on business model within the scope of Industrialised Building System (IBS) and supported by other industries. All data and information were obtained directly from the databases, books, research papers and other written materials such as national and international journals, proceedings, and newsletters.

\section{The Business Model Elements}

Many definitions of the business model are available in the literature but one well-known definition is by Magretta (2002). She defined business model as "stories that explain how enterprises work". This definition is relatively short and to some degree, pragmatic. Other definitions concentrate more on strategy and organizational theory, or centre around designing transactions and/or activity systems (Zott, 2007; Zott \& Amit, 2010). Meanwhile, according to Osterwalder et al. (2005), a business model is a conceptual tool that comprises of a set of elements and the relationships involved, and permits conveying the business logic of a particular firm. Therefore, one must decide which concepts and relationships give a comprehensive description and illustration of the value delivered to customers, the methods to be used and the respective financial consequences.

Based on the definition above, it can be said that business models contain a set of elements and their relationships which can express the business logic of a firm (Mokhlesian \& Holmén, 2012; Osterwalder et al., 2005). The concept of business model is cast as an analytical tool which provides a universal perspective on the way a company does business and the activities and resources mobilized (Kindström, 2005; Zott et al., 2011). The position of the business model in the company determines the blueprint of how a company carries out its business. The business model acts as a building plan that lets designing and working on the business structure and systems which includes the company's functioning and physical forms (Osterwalder et al., 2005). Pekuri et al. (2013) stated that business models are viewed as important in ensuring the success of a business because they explain how value is created by companies for their customers, therefore generating profit from their operations. A good business model will have the ability to isolate a company from its competitors by forming a competitive advantage.

According to Osterwalder et al., (2005), and Chesbrough and Rosenbloom (2002) the specific components of a business model element, which should be considered in designing a business 
model, vary between studies. In generating the business model elements for this study, sixteen studies on business models were reviewed as can be seen in Table 1 . This study uses the IBS business model developed by Brege et al. (2014) as a base line concept with synthetisation of the other business models. Selecting and adapting each element of the business model involves the three criteria below: (1) the frequency of incidence among the studied business models; (2) the appropriateness of the category to be applied within the context of the contractor's firm; and (3) the appropriateness of the category to be applied particularly with the context of IBS. The components of a business model used for this study are described below.

\section{Target customer}

Target customer is very important in business because it defines the different groups or segments of customers to be offered value (Brege et al., 2014; Lessing \& Brege, 2015; Mokhlesian \& Holmén, 2012; Osterwalder et al., 2005). Customer segments can be categorized into public, private corporate and individuals (Blackmore, 1990). The customers in the construction industry is called clients. They are among the most important stakeholders in the construction supply chain and are most likely from a firm or group that sets up a construction project (Boyd \& Chinyio, 2008). Clients are normally the ones who trigger the design and production of construction facilities (Qi et al., 2010). Targeting customers in the business of construction is not clear-cut (Ofori, 2000). The contractor will need to design the system that meets the customers' requirements (Barlow \& Ozaki, 2003). Moreover, targeting customers is very important for companies that want to venture in IBS because payments made to the IBS contractor cannot be the same amount as what is paid for conventional projects, since the starting cost is not the same. It is therefore vital for IBS contractors to be paid the initial payment from the client in order for their business to sustain (Dzulkalnine et al., 2016; Hadi et al., 2017).

\section{Market segments}

The identification of market segment is important in business (Brege et al., 2014; Chesbrough, 2007; Kindström, 2010; Lessing \& Brege, 2015; Lou \& Kamar, 2012; Nenonen \& Storbacka, 2010). There is a need for contractors to identify a suitable market segment in the IBS market. The market segment in IBS business in the Malaysian construction industry can be divided into public (Mohamad et al., 2016) and private sectors (Nawi et al., 2015). The identification of market segmentation will also lead to market demand. According to Lou and Kamar (2012), the market demand for IBS is essential because adoption is determined by clients' willingness to invest in a premium product offered by the contractor. The demand should also relate to demands of macroeconomic. The industry player will need to enter and concentrate on a certain market sectors such as high end, high quality or affordable, low cost, or only on public buildings in which the contracts and designs are monotonous (Lou \& Kamar, 2012). Thus, understanding the needs and priorities of the market and customer must be incorporated in the design of IBS concepts and its production systems (Lessing \& Brege, 2018).

\section{Marketing Strategy}

Strategy is important in business positioning (Brege et al., 2014; Chesbrough, 2007; Kindström, 2010; Zairul, 2017). Lou and Kamar opined (2012) that in adopting IBS require strategy in business, and this is essential in measuring the activities of the project. Contractors require strategy for a better approach in their projects and for business sustainability (Hamid 
et al., 2011). Brege et al. (2014) stated that practical business models have to build resilient marketing push mechanisms to 'create' a market for IBS. When a proper market segment is identified, marketing segmentation should lead to the design of distinctive marketing strategies for each segment in relation to the four Ps, namely the product, price, place, and promotion (Brege et al., 2014; Lessing \& Brege, 2015; Lou \& Kamar, 2012). The contractor will need to promote a huge variety of products and services to customers with third-party accreditation on products and systems (Kamar et al., 2012). This is to convince the customers that the product and services offered by them are of good quality. According to Kotler (1997), in marketing, prosperous companies often succeed in creating a mixture of push and pull effects. Push effects are built through effective sales and distribution, and a high level of availability when the customer is willing to buy. Pull effects originate from customers' demand for a company's offering, which could be the effect of high level of brand awareness and loyalty (Brege et al., 2014).

\section{Distribution channel}

Distribution channel is very important in business because it clarifies the different means of the company to connect with its customers (Johnson et al., 2008; Osterwalder et al., 2005; Pekuri et al., 2013). Mokhlesian and Holmén (2012) stated that the distribution channel in construction refers to how a construction company approaches their client in order to promote or sell their products and services. This can be in the form of direct approach or through tendering process and contracts. Drakulevski and Nakov (2014) mentioned that it is the process of achieving a full alignment with the identified needs and includes a proper way of handling the customers, through the distributive channels. They also mentioned the distribution channel integrates all communicational approaches in order to create a sense of satisfaction for specific customers (Drakulevski \& Nakov, 2014). While Mokhlesian \& Holmén (2012) suggested that this element plainly illustrates that on one hand the business model element is associated with the expertise of the construction company in meeting its customers' needs while on the other hand the target customers that a construction company identifies would detail the manner that the company has to deal with its customers.

\section{Role in supply chain}

The roles of a company in the construction process is also important in order to ascertain the extent of control that the company has in the IBS construction supply chain (Brege et al., 2014; Lessing \& Brege, 2015). According to Brege et al. (2014), the prefabrication strategy of a company must be accompanied by a strategy for the role that the company aims in the process of construction. For example, if the company aims for the volume of elements, the company will need to have a high level of control in the design phase and total onsite control, making the role of the contractor the most suitable. Furthermore, the company can accept different market roles in the building process; being a contractor, product supplier, developer or a blend of these roles, depending on the company's business strategy (Brege et al., 2014; Lessing \& Brege, 2015). A study conducted by Kamar and Hamid (2011) found that the companies involved in IBS hold the roles as producer, designer, and installer of an IBS proprietary system across the supply chain. The reason is to position themselves in the IBS market and to be the sole solution provider for clients that want to use IBS in their construction project. 


\section{Supplier relationship}

Lou and Kamar (2012) pointed out that the teamwork between suppliers and contractors is frail in most cases and this is due to the fragmentation of the construction industry. Contractors must have good relationship with suppliers to maintain a stable production system, and it must be based on long-term collaborations (Johnson et al., 2008; Lessing \& Brege, 2015, Lessing \& Brege, 2018; Pekuri et al., 2013). By maintaining good relationship with suppliers, contractors are able to deliver better in the competitive construction industry (Tan et al., 2012). This is accomplished by developing the procurement system and the construction supply chain (Lou \& Kamar, 2012). Kamar and Hamid (2011) suggested partnering initiatives and embracing open collaborative environment. Pairing up with suppliers from the beginning stages of the project is crucial to warrant efficient and timely delivery of components and services (Goh \& Loosemore, 2017; Lou \& Kamar, 2012; Rashid, Abdullah, \& Ismail, 2019). Embracing open collaborative environment is to improve efficiencies and competitiveness. Contractors will need to sustain good relationships and cooperate with suppliers who produce or deliver services and products (Kamar \& Hamid, 2011).

\section{Product}

Product is part of value proposition which is to be offered to customers (Lessing \& Brege, 2015; Mokhlesian \& Holmén, 2012; Osterwalder et al., 2005). The adoption of IBS relies on the inclination of the clients to spend and to get a premium product offered by IBS (Lou \& Kamar, 2012). IBS products can come in the form of modules, elements, or component systems (Brege et al., 2014). Usually, IBS companies offer particular varieties of products, normally based on a structure that allows solutions to be repeated (Lessing \& Brege, 2015). The products can be steel framing system, pre-cast concrete system, timber framing system, formwork system, innovative system or block work system. The most popular IBS in Malaysia is the precast concrete elements (Azman et al., 2011). The product offered by this system are precast concrete columns, slabs, beams, 3-D components (e.g. balconies, staircases, toilets, lift chambers, refuse chambers), walls, lightweight precast concrete, and permanent concrete formworks (Din et al., 2012). In adopting IBS, the contractor will need to offer higher quality of products to clients (Tan et al., 2012) with third-party accreditation on products and systems (Hamid et al., 2011).

\section{Design}

In order to adopt IBS, contractors should convert their business process in the direction of incorporating design and manufacturing in their chain of supply (CIDB, 2014; Kamar et al., 2012; Pekuri et al., 2013). The companies need to put themselves in the position as a complete solution provider for IBS, offering clients a wide array of services from design, manufacturing and installation (Hamid et al., 2011; Nawi et al., 2015). The capability to manage the supply chain and administer the process of integration is a key feature towards the success of the IBS business (Hamid et al., 2011). Hung et al. (2015) stated that most project designs in Malaysia employ the conventional method. For IBS to be adopted into projects, the projects have to be transformed into IBS first because conventional designs do not take into account the modularity and manufactural ability of IBS components. IBS design process is a critical feature of successful IBS adoption (Lessing \& Brege, 2015; Mohamad et al., 2009; Zairul, 2017) because it depends on the large volume and repetitive design that would really compensate the prior investment of set up prefabrication facilities (Hamid et al., 2011). The 
contractors involved in IBS must possess design capabilities to undertake IBS projects. This can be either in-house or outsourced (Kamar et al., 2012). They will also need to provide a design with good quality, construction time which is faster and also cost saving to attract clients (Jabar et al., 2013).

\section{Manufacturing}

As pointed out by Kamar et al. (2012), the companies that are involved in IBS may not necessarily have in-house capabilities to manufacture building components as they can also outsource the systems and implementations (CIDB, 2014; Morris et al., 2005; Pekuri et al., 2013). Contractors who operate without the manufacturing capability are expected to purchase building components from IBS manufacturers but this will cost them a huge amount of the contract sum (Kamar et al., 2012). By having the capability to manufacture, contractors can be in control of the process and the profit or loss can be anticipated and accustomed accordingly across IBS projects selected by the company (Kamar \& Hamid, 2011). The requirements of physical capital linked to IBS will differ depending on the choices a contractor makes regarding developing their own components (individually or with existing partnering manufacturers) or merely purchasing components which are ready-made from reputable manufacturers (Goh \& Loosemore, 2017).

\section{Installation}

Besides design and manufacturing services, contractors involved in IBS are also offering the installation service of the IBS components to clients (Kamar et al., 2012). The installation of building components will continue at the construction site after the manufacturing work have been completed in the manufacturing facility. The installation work may be done in-house or by outsourcing it to specialised installers (Goh \& Loosemore, 2017; Kamar et al., 2012). The installation process is part of the service that the contractors offer in order for them to become a one stop centre to clients (CIDB, 2014; Kamar et al., 2012; Pekuri et al., 2013).

\section{Standardisation}

According to Pan et al., (2008) the obstructions significant to IBS adoption include high capital budgets and lack of frugalities of scale and scope. IBS companies will need to offer a standardized solution offering to customers (Brege et al., 2014; Morris et al., 2005). This include offering a standardisation of design and building components. The low standardisation of components will hinder the effective usage of IBS as the individualised components which do not fit into other projects will upsurge original costs attributable to the cost of the mould and design (Din et al., 2012). Xue et al., (2017) suggested that standardised designs will promote mass production and that economies of scale can thus reduce the cost of products. This is mainly because standardisation can improve proficiency and productivity rates of the workers and reduce the labour costs.

\section{Customisation}

Customisation is a menu-driven approach, where customers choose features and products that are personalised to specific customer needs (Barlow \& Ozaki, 2003; Din et al., 2012; Lessing \& Brege, 2015). Contractors should be able to offer customisation of buildings for clients as this is to produce the highest price for IBS and to offer the best interests of the clients (Lessing \& Brege, 2015; Zairul, 2017). Clients nowadays, especially those in the private sector, demand more in terms of the aesthetic value of the building architecture design (Din 
et al., 2012). Therefore, it is necessary to construct buildings according to customer needs and wants (Schoenwitz et al., 2012). According to Morris et al. (2005), contractors nowadays should be able to offer both standardized to customized products to clients depending on the demand.

\section{Production Method}

The production method for the fabrication of IBS components is important for operational platform (Brege et al., 2014; Lessing \& Brege, 2015, Lessing \& Brege, 2018). It can be done whether offsite or onsite depending of the capability of the contractor (CIDB, 2003). As for offsite production, the fabrication of building components generally takes place at a particular facility located in a factory where numerous materials are combined to construct building components (Tatum et al., 1986). Meanwhile, the onsite production is done at the construction site which will result in cost savings in relation to transportation (Azman et al., 2012; Jabar \& Ismail, 2014). This is done when the contractors do not have a proper factory to do the production work (Mohamed et al., 2019). The production of building components at a factory has a good effect on occupational safety as onsite hours and heavy lifting are minimised. Moreover, it reduces the environmental impact associated with the transportation of materials to construction sites (Bhattacharjee et al., 2016). However, it requires heavy investments to set up such facilities. Based on assumptions made by Kamar et al. (2014) and Mohamed et al. (2018), the estimated investment required to setup the small scale facilities for SMEs is around RM 1.25 million. In order for the SME contractors to move from the conventional method to IBS, they need to select a production method that is suitable for them.

\section{Key Resources}

Resources are essential in business as it is necessary for the operation of the business (Brege et al., 2014; Mokhlesian \& Holmén, 2012; Osterwalder et al., 2005). According to Hamid et al. (2011), the process of moving from conventional construction methods to IBS demands a huge amount of resources where the contractors will require the necessary resources to setup the IBS business. The key resources required for the adoption of IBS are financial, physical and human resources; i.e. site, logistic, manufacturing plant, designers, engineers and technicians (Brege et al., 2014; Goh \& Loosemore, 2017; Kamar et al., 2014; Zairul, 2017). Financial resources are described by Green and Brown (1997) as funds from any monetary source used to begin, run and develop the business. These funds are known as the working capital of a business (Elsas et al., 2014). Kamaruddin et al., (2013) and Musa et al., (2016) stated that in order to implement a new technology into an enterprise, financial resources are crucial. The necessary elements to setup the IBS business such as people, technology, management and process will involve cost and money. Meanwhile, Goh and Loosemore (2017) mentioned that physical resources of a business include raw materials or goods, machinery and equipment, plants and structures used to produce the products and services of an organisation. While, human resources refer to the people who make up an organization's workforce and their contribution, skills and capacities associated with them such as designers, engineers and technicians.

\section{Core competencies}

This business element is necessary for a company to implement the IBS business (Mokhlesian \& Holmén, 2012; Nenonen \& Storbacka, 2010; Osterwalder et al., 2005; Pekuri et al., 2013). 
Skills and competencies are very important in IBS adoption (Lou \& Kamar, 2012). According to Kamar et al., (2010) successful implementation of IBS entails experienced workers with the technical capability in design, planning \& scheduling, organizing and controlling functions, pertaining to the coordination, production and distribution of components. Kamar et al. (2014) and Brege et al. (2014) also added that organisation knowledge, effective communication and process coordination are also important for the implementation of IBS. Because of the high core competencies, most of the IBS contractors who succeeded have inhouse manufacturing systems and design capabilities to undertake the IBS projects (Kamar et al., 2012). The company can benefit from an organized production process once traditional design processes are put to practice, providing quite infinite design flexibility; and because the company has both in-house design and production competencies, important knowledge is recycled within the organization (Lessing \& Brege, 2018).

\section{Supply chain management}

Supply chain management is the administration of system relationships of organisations in pursuing the development of business process and performance (Nawi et al., 2010). This business model element is important for the smooth implementation of IBS business (CIDB, 2014; Hedman \& Kalling, 2003; Lessing \& Brege, 2015, Lessing \& Brege, 2018; Morris et al., 2005). The supply chain in IBS demands close control of materials and resource management to safeguard stability and punctual construction components deliveries at site (Fauzi et al., 2018; Kamar \& Hamid, 2011). The supply chain has to be managed in a way that lets the contractors have full control of the process whilst aiming to increase efficiencies and competitiveness (Kamar \& Hamid, 2011).

\section{Continuous improvement}

The IBS construction process is fundamentally diverse from the conventional projectoriented methods in the usage of building systems, prefabrication methods, and repetitive processes that facilitate continuous technological and methodological developments (Lessing et al., 2015; Lessing \& Brege, 2018). Uusitalo et al. (2017) stated that IBS production is one of the major bottlenecks within the company's business processes so the continuous improvement process needs to be strengthened for the efficiency of the production. Continuous improvement is part of the management process whereby the processes of IBS delivery are continuously evaluated and amended in the light of efficiency, effectiveness and flexibility (Kamar, 2011). According to Lessing and Brege (2015), continuous improvements should be based on process experience and customer feedback. In order to serve the customers better, contractors will need to frequently improve their operation in adopting IBS.

\section{Sales management}

The sales of IBS components can be done through the company's own sales staff or sales partners (CIDB, 2014; Lessing \& Brege, 2018). Brege et al. (2014) found that for the companies to be influential in IBS business, marketing and sales must be focused on public and private clients and architects, and also to big leading contractors. Companies which are efficacious are normally successful in creating a mixture of push and pull effects to clients (Kotler, 1997). Push effects are assembled through effective sales and delivery, and a high degree of availability when customers are prepared to buy. Pull effects originate from the customers' own plea for a company's offering, which could stem from a high degree of brand awareness and brand loyalty. 


\section{Partnering}

This business component depicts that the network of cooperative settlements with other companies are essential in order to efficiently offer and commercialize value (Mokhlesian \& Holmén, 2012; Osterwalder et al., 2005; Pekuri et al., 2013). Mokhlesian and Holmén (2012) stated that partner network is closely linked to a company's capabilities because when the company realizes they do not have access to or can construct the right relevant capabilities for certain projects, they normally look for new partners or collaborators. Lou \& Kamar (2012) suggested that IBS adopters may want to be able to work together with clients, manufacturers, and designers from the start to the completion of IBS projects. In order to speed up change and expedite the learning curve, adopters need to pair up with reputable organizations with adequate technical knowledge. They also mentioned that in order to secure contracts in public and private projects, a strategic coalition with other companies is vital.

Table 1: Business model elements from previous studies

\begin{tabular}{|c|c|c|c|c|c|c|c|c|c|c|c|c|c|c|c|c|c|}
\hline $\begin{array}{l}\text { No } \\
\text {. }\end{array}$ & $\begin{array}{l}\text { Business model elements } \\
\text { / Authors }\end{array}$ & 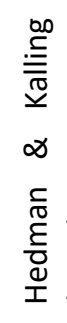 & 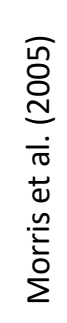 & 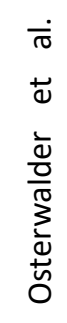 & 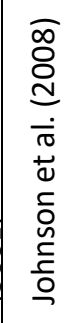 & 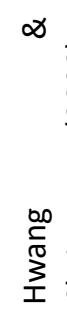 & 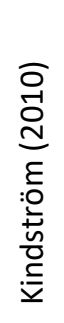 & 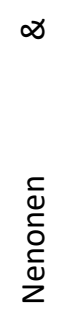 & 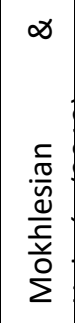 & 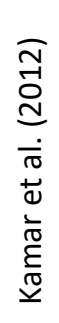 & 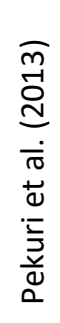 & 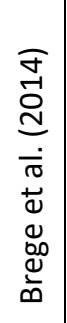 & 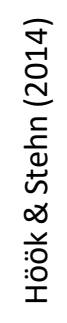 & 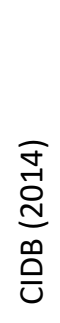 & 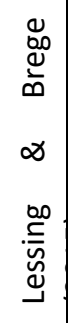 & 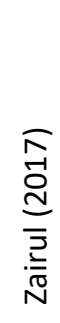 & 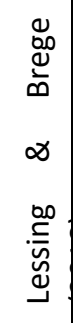 \\
\hline 1. & Target Customers & 1 & 1 & 1 & 1 & 1 & & 1 & 1 & & 1 & 1 & & & 1 & 1 & 1 \\
\hline 2. & Market segments & & l & & & & I & I & & I & & I & & & I & & I \\
\hline 3. & Marketing Strategy & & l & & & & I & & & I & & I & I & & & I & \\
\hline 4. & Distribution channel & & I & 1 & I & & & & I & & I & & & & & 1 & \\
\hline 5. & Role in supply chain & & & & & & & & & & & I & & & 1 & & I \\
\hline 6. & Supplier relationship & & I & & I & & & I & & & I & & & & I & & I \\
\hline 7. & Product & 1 & 1 & 1 & 1 & 1 & I & & 1 & & 1 & & 1 & & 1 & 1 & 1 \\
\hline 8. & Design & & & & 1 & & & 1 & & 1 & 1 & & & 1 & 1 & 1 & 1 \\
\hline 9. & Manufacturing & & 1 & & 1 & 1 & & & & 1 & 1 & & & 1 & & & \\
\hline $\begin{array}{l}10 \\
.\end{array}$ & Installation & & & & l & & & & & I & / & & & l & & & \\
\hline 11 & Standardisation & & / & & & & & & & & & / & & & & & \\
\hline 12 & Customisation & & / & & & & & & & & & & & & / & / & / \\
\hline 13 & Production method & & / & & & & & & & & & / & & / & / & / & / \\
\hline 14 & Key resources & / & & / & / & / & / & / & / & & / & / & & & & / & \\
\hline 15 & Core competencies & & & / & & / & & / & / & & / & / & & & & & \\
\hline 16 & $\begin{array}{l}\text { Supply chain } \\
\text { management }\end{array}$ & / & / & & & & & & & & & & & / & / & & / \\
\hline 17 & $\begin{array}{l}\text { Continuous } \\
\text { improvement }\end{array}$ & & & & & & & & & & & & & & / & / & / \\
\hline 18 & Sales Management & & & & & & & & & & & & & / & / & / & / \\
\hline 19 & Partnering & & & l & l & & & / & / & & / & & & / & & / & \\
\hline
\end{tabular}




\section{Conclusion}

SME contractors will need to establish more innovative business models and plans for turnover growth. From the study conducted nineteen of the business model elements have been identified. They are 1. Target Customers, 2. Market Segments, 3. Marketing Strategy, 4. Distribution Channel, 5. Role in Supply Chain, 6. Supplier Relationship, 7. Product, 8. Design, 9. Manufacturing, 10. Installation, 11. Standardisation, 12. Customisation, 13. Production Method, 14. Key Resources, 15. Core Competencies, 16. Supply Chain Management, 17. Continuous Improvement, 18. Sales Management, and 19. Partnering. These business model elements are essential towards guiding the SME contractors to move from conventional construction method to IBS practice and to increase their performance in IBS business.

\section{Corresponding Author}

Mohamed Rizal Mohamed

School of Architecture, Building and Design, Faculty of Innovation and Technology, Taylor's University, No. 1 Jalan Taylor's 47500 Subang Jaya Selangor, Malaysia

Email: MohamedRizal.Mohamed@taylors.edu.my.

\section{References}

Alinaitwe, H. M., Mwakali, J., \& Hansson, B. (2006). Assessing the degree of industrialisation in construction - a case of Uganda. Journal of Civil Engineering and Management, 12(3), 221-229. https://doi.org/10.1080/13923730.2006.9636396

Azman, M. N. ., Majid, T. A., Ahamad, M. S. S., \& Hanafi, M. H. (2011). A study on the trend of the use of IBS components and the setting UP of IBS manufacturing factories in the malaysian construction industry. Malaysian Construction Research Journal, 9(2), 18-30.

Azman, M. N. A., Ahamad, M. S. S., \& Wan Husin, W. M. A. (2012). Comparative study on prefabrication construction process. Surveying Research Journal, 2(1), 45-58. https://doi.org/10.1016/j.marenvres.2015.10.010

Barlow, J., \& Ozaki, R. (2003). Achieving "customer focus" in private housebuilding: Current practice and lessons from other industries. Housing Studies, 18(1), 87-101. https://doi.org/10.1080/0267303032000076858

Bhattacharjee, S., Pishdad-Bozorgi, P., \& Ganapathy, R. (2016). Adoption of Pre-Fabrication in Construction to Achieve Sustainability Goals: An Empirical Study. Construction Research Congress 2016, 1050-1060. https://doi.org/doi:10.1061/9780784479827.106

Blackmore, C. (1990). The Client's Tale: The Role of the Client in Building Buildings. RIBA Publications.

Blismas, N., Pasquire, C., \& Gibb, A. (2006). Benefit evaluation for off-site production in construction. Construction Management and Economics, 24(2), 121-130. https://doi.org/10.1080/01446190500184444

Boyd, D., \& Chinyio, E. (2008). Understanding the construction client. John Wiley \& Sons.

Brege, S., Stehn, L., \& Nord, T. (2014). Business models in industrialized building of multistorey houses. Construction Management and Economics, 32(Nos. 1-2), 208-226. https://doi.org/10.1080/01446193.2013.840734

Chesbrough, H. (2007). Business model innovation: It's not just about technology anymore. Strategy and Leadership, 35(6), 12-17. https://doi.org/10.1108/10878570710833714

Chesbrough, H., \& Rosenbloom, R. S. (2002). The role of the business model in capturing value from innovation: evidence from Xerox Corporation's technology spin-off companies. Industrial and Corporate Change, 11(3), 529-555. 
http://dx.doi.org/10.1093/icc/11.3.529

CIBD. (2003). IBS roadmap 2003-2010.

CIDB. (2003). Industrialised Building Systems (IBS) Roadmap 2003-2010. Construction Industry Development Board (CIDB).

CIDB. (2014). An Introduction of Industrialised Building System: Manual For Developer. CIDB Malaysia.

CIDB. (2015). Construction Industry Transformation Programme 2016 - 2020. Construction Industry Development Board (CIDB).

CIDB. (2016). Industrialised Building Systems in Malaysia 2008 - 2013 Pojects. Construction Industry Development Board (CIDB), Malaysia.

Din, M. I., Bahri, N., Dzulkifly, M. A., Norman, M. R., Kamar, K. A. M., \& Hamid, Z. A. (2012). The adoption of Industrialised Building System (IBS) construction in Malaysia: The history, policies, experiences and lesson learned. Proceedings of the 2012 29th International Symposium of Automation and Robotics in Construction (ISARC), Eindhoven, The Netherlands, 26-29.

Drakulevski, L., \& Nakov, L. (2014). Managing Business Model As Function of Organizational Dynamism. Management - Journal for Theory and Practice of Management, 19(72), 3744. https://doi.org/10.7595/management.fon.2014.0025

Dzulkalnine, N., Azman, M. N. A., Bing, K. W., Habidin, N. F., \& Ayub, A. R. (2016). Issues of payment procurement process for industrialised building system (IBS) project. Jurnal Teknologi, 78(5-10), 11-15. https://doi.org/10.11113/jt.v78.8826

Elsas, R., Flannery, M. J., \& Garfinkel, J. A. (2014). Financing Major Investments: Information about Capital Structure Decisions*. Review of Finance, 18(4), 1341-1386. https://doi.org/10.1093/rof/rft036

Fauzi, M. A., Hasim, S., \& Mustafa, M. A. (2018). Supply Chain Management (SCM) on Industrialised Building System (IBS) in Construction Industry: Supplier Perspective. In N. A. Yacob, N. A. Mohd Noor, N. Y. Mohd Yunus, R. Lob Yussof, \& S. A. K. Y. Zakaria (Eds.), Regional Conference on Science, Technology and Social Sciences (RCSTSS 2016) (pp. 445454). Springer Singapore.

Gibb, A., \& Isack, F. (2003). Re-engineering through pre-assembly: client expectations and drivers. Building Research \& Information, 31(2), 146-160.

https://doi.org/10.1080/09613210302000

Goh, E., \& Loosemore, M. (2017). The impacts of industrialization on construction subcontractors: a resource based view. Construction Management and Economics, 35(5), 288-304. https://doi.org/10.1080/01446193.2016.1253856

Goodier, C., \& Gibb, A. (2007). Future opportunities for offsite in the UK. Construction Management and Economics, 25(6), 585-595.

https://doi.org/10.1080/01446190601071821

Goulding, J. S., Pour Rahimian, F., Arif, M., \& Sharp, M. D. (2015). New offsite production and business models in construction: priorities for the future research agenda. Architectural Engineering and Design Management, 11(3), 168-184.

https://doi.org/10.1080/17452007.2014.891501

Greene, P. G., \& Brown, T. E. (1997). Resource needs and the dynamic capitalism typology. Journal of Business Venturing, 3(12), 161-173.

Hadi, N. A., Muhammad, W. M. N. W., \& Othman, M. K. F. (2017). Critical factors of implementing Industrialised Building System in Sarawak: A research on SMEs. 7th International Conference on Environment and Industrial Innovation. 
https://doi.org/10.1088/1755-1315/67/1/012006

Hamid, Z. A., Kamar, K. A. M., Ghani, M. K., Zain, M. Z. M., \& Rahim, A. H. A. (2011). Business Strategies of Contractors in Industrialised Building Systems (IBS) Construction. International Construction Business and Management Symposium (ICBMS 2011), September, 148-155. http://www.vertilite.asia/f/2012/11/IBS-Business-Strategy-forContractors.pdf

Hamid, Z. A., Kamar, K. A. M., Zain, M. Z. M., Ghani, M. K., \& Rahim, A. H. A. (2008). Industrialised Building Systems (IBS) in Malaysia: The Current State Malaysia and R\&D Initiatives. Malaysian Construction Research Journal, 2(1), 1-13.

Hanafi, M. H., Abdullah, S., Razak, A. A., \& Nah, F. M. (2015). Contractors' Perspective on the Benefits of Implementing Industrialized Building System (IBS). International Journal of Sustainable Construction Engineering \& Technology, 6(1), 44-51.

Haron, N. A., Abdul-Rahman, H., \& Hanid, M. (2009). A Literature Review of The Advantages and Barriers to The Implementation of Industrialised Building System (IBS) In Construction Industry. Malaysian Construction Research Journal, 4(1), 14-18.

Hedman, J., \& Kalling, T. (2003). The business model concept: Theoretical underpinnings and empirical illustrations. European Journal of Information Systems, 12(1), 49-59. https://doi.org/10.1057/palgrave.ejis.3000446

Höök, M., \& Stehn, L. (2014). Exploring the management of multiple business models in one company. Proceedings 30th Annual Association of Researchers in Construction Management Conference, ARCOM 2014, September, 1315-1324. http://www.scopus.com/inward/record.url?eid=2-s2.084911366693\&partnerID=tZOtx3y1

Hung, F. C., Hamid, Z. A., Din, M. I., \& Norman, M. R. (2015). Study on Industrialised Building System (IBS) Adoption Level and Contractors' Readiness in Malaysia 2013. Malaysian Construction Research Journal, 17(1), 1-19.

Hwang, J., \& Christensen, C. M. (2008). Disruptive Innovation In Health Care Delivery: A Framework For Business-Model Innovation. Health Affairs, 27(5), 1329-1335. https://doi.org/10.1377/hlthaff.27.5.1329

Jabar, I. L., \& Ismail, F. (2014). Challenges in the Management of IBS Construction Projects. Asian Journal of Environment-Behaviour Studies, 5(18), 1-9.

Jabar, I. L., Ismail, F., \& Mustafa, A. A. (2013). Issues in Managing Construction Phase of IBS Projects. Procedia - Social and Behavioral Sciences, 101, 81-89.

https://doi.org/10.1016/j.sbspro.2013.07.181

Johnson, M. W., Christensen, C. M., \& Kagermann, H. (2008). Reinventing your business model. Harvard Business Review, 86(12), 57-68.

Kamar, K. A. M. (2011). Critical Success Factors to Industrialised Building System (IBS) Contractor (Issue January). PhD Thesis, University of Salford, UK.

Kamar, K. A. M., Azman, M. N. A., \& Nawi, M. N. M. (2014). IBS survey 2010: Drivers, barriers and critical success factors in adopting industrialised building system (IBS) construction by G7 contractors in Malaysia. Journal of Engineering Science and Technology, 9(4), 490501.

Kamar, K. A. M., \& Hamid, Z. A. (2011). Supply chain strategy for contractor in adopting industrialized building system (IBS). Australian Journal of Basic and Applied Sciences, 5(12), 2552-2557.

Kamar, K. A. M., Hamid, Z. A., \& Alshawi, M. (2010). The critical success factors (CSFs) to the implementation of industrialised building system (IBS) in Malaysia. Proceedings in CIB 
World Congress 2010, Salford, 10-13. http://www.vertilite.asia/f/2012/11/IBS-CriticalSuccess-Factors.pdf

Kamar, K. A. M., Hamid, Z. A., Ghani, M. K., Rahim, A. H. A., Zain, M. Z. M., \& Ambon, F. (2012). Business strategy of large contractors in adopting industrialised building system (IBS): The Malaysian case. Journal of Engineering Science and Technology, 7(6), 774-784.

Kamaruddin, S. S., Mohammad, M. F., \& Mahbub, R. (2013). Enhancing the Quality of Life by Adopting IBS: An Economic Perspective on Mechanisation and Automation. Procedia Social and Behavioral Sciences, 101, 71-80. https://doi.org/https://doi.org/10.1016/j.sbspro.2013.07.180

Kasim, N., Al-shami, M. H., Latiffi, A. A., Ibrahim, U., Zainal, R., \& Noh, H. M. (2019). Improving Contractors ' Practices of Industrialized Building System (IBS) Implementation in Construction Industry. Journal of Technology Management and Business, 6(3), 40-49. https://doi.org/10.30880/jtmb.2019.06.03.005

Kindström, D. (2005). The integration of e-business into mature and established companies: a business model approach. Linköpings universitet.

Kindström, D. (2010). Towards a service-based business model - Key aspects for future competitive advantage. European Management Journal, 28(6), 479-490. https://doi.org/10.1016/j.emj.2010.07.002

Kotler, P. (1997). Marketing management, analysis, planning, implementation, and control. London: Prentice-Hall International.

Lessing, J., \& Brege, S. (2015). Business models for product-oriented house-building companies - experience from two Swedish case studies. Construction Innovation, 15(4), 449-472.

Lessing, J., \& Brege, S. (2018). Industrialized Building Companies' Business Models: Multiple Case Study of Swedish and North American Companies. Journal of Construction Engineering and Management, 144(2), 5017019.

https://doi.org/10.1061/(ASCE)CO.1943-7862.0001368

Lessing, J., Stehn, L., \& Anders, E. (2015). Industrialised house-building development and conceptual orientation of the field. Construction Innovation, 15(3), 378-399.

Lou, E. C. W., \& Kamar, K. A. M. (2012). Industrialized Building Systems: Strategic Outlook for Manufactured Construction in Malaysia. Journal of Architectural Engineering, 18(2), 6974. https://doi.org/10.1061/(ASCE)AE.1943-5568.0000072

Magretta, J. (2002). Why Business Models Matter - Harvard Business Review. In Harvard Business Review. https://doi.org/10.1016/j.cub.2005.06.028

Majid, T. A., Azman, M. N. A., Zakaria, S. A. S., Yahya, A. S., Zaini, S. S., Ahamad, M. S. S., \& Hanafi, M. H. (2011). Quantitative Analysis on the Level of IBS Acceptance in the Malaysian Construction Industry. Journal of Engineering Science and Technology, 6(2), 179-190.

Mohamad, D., Ramli, M. Z., Danuri, H., \& Sapuan, W. K. (2016). Demand of the industrialized building system (IBS) implementation in Malaysian government projects. Journal of Scientific Research and Development, 3(4), 77-82. http://jsrad.org/wpcontent/2016/Issue 4, 2016/13jj.pdf

Mohamad, M. I., Zawawi, M., \& Nekooie, M. A. (2009). Implementing Industrialised Building System (IBS) in Malaysia: Acceptance and Awareness Level, Problem and Strategies. Malaysian Journal of Civil Engineering, 21(2), 219-234.

Mohamed, M. R., Mohammad, M. F., Mahbub, R., Ramli, M. A., Gunasagaran, S., \& Halim, S. M. A. (2019). Business Strategy of Small and Medium-Sized Enterprise Construction 
Companies in Adopting Industrialised Building System in Malaysia. International Journal of Academic Research in Business and Social Sciences, 9(9), 1036-1048. https://doi.org/10.6007/IJARBSS/v9-i9/6407

Mohamed, M. R., Mohammad, M. F., Mahbub, R., Ramli, M. A., \& Jamal, K. A. A. (2018). The Issues and Challenges of Small and Medium-Sized Contractors in Adopting Industrialised Building System. International Journal of Engineering \& Technology, 7(3.25), 432-436. https://doi.org/dx.doi.org/10.14419/ijet.v7i3.25.17725

Mokhlesian, S., \& Holmén, M. (2012). Business model changes and green construction processes. Construction Management and Economics, 30(9), 761-775. https://doi.org/10.1080/01446193.2012.694457

Morris, M., Schindehutte, M., \& Allen, J. (2005). The entrepreneur' s business model : toward a unified perspective. Journal of Business Research, 58(6), 726-735. https://doi.org/10.1016/j.jbusres.2003.11.001

Musa, M. F., Mohammad, M. F., Yusof, M. R., \& Ahmad, R. (2016). Industrialised Building System Modular System (IBSMS) Organisational Readiness Framework. Procedia - Social and Behavioral Sciences, 222, 83-92. https://doi.org/10.1016/j.sbspro.2016.05.191

Na, L., \& Roger, W. L. (2008). Designers' and General Contractors' Perceptions of Offsite Construction Techniques in the United State Construction Industry. International Journal of Construction Education and Research, 4(3), 177-188.

https://doi.org/10.1080/15578770802494565

Nawi, M. N. M., Azman, M. N. A., Baluch, N., Kamar, K. A. M., \& Hamid, Z. A. (2015). Study on the Use of Industrialised Building System in Malaysia Private Construction Projects. ARPN Journal of Engineering and Applied Sciences, 10(17), 7368-7374.

Nawi, M. N. M., Lee, A., \& Arif, M. (2010). The IBS Barriers in the Malaysian Construction Industry: A Study in Construction Supply Chain Perspective. In In TG57-Special Track 18th CIB World Building Congress May 2010 Salford (p. 77).

Nawi, M. N. M., Lee, A., Azman, M. N. A. A., \& Kamar, K. A. M. (2014). FRAGMENTATION ISSUE IN MALAYSIAN INDUSTRIALISED BUILDING SYSTEM (IBS) PROJECTS. Journal of Engineering Science and Technology, 9(1), 97-106.

Nenonen, S., \& Storbacka, K. (2010). Business model design: conceptualizing networked value co-creation. International Journal of Quality and Service Sciences, 2(1), 43-59. https://doi.org/10.1108/17566691011026595

Ofori, G. (2000). Greening the construction supply chain in Singapore. European Journal of Purchasing and Supply Management, 6(3-4), 195-206. https://doi.org/10.1016/S09697012(00)00015-0

Osterwalder, A., Pigneur, Y., \& Tucci, C. L. (2005). Clarifying business models: origins, present, and future of the concept. Communications of the Association for Information Systems, 15(1), 1-43. https://doi.org/10.1.1.83.7452

Pan, W. (2006). A decision support tool for optimising the use of offsite technologies in housebuilding. Ph.D Thesis, Loughborough University, U.K.

Pan, W., Gibb, A. G. F., \& Dainty, A. R. J. (2008). Leading UK housebuilders' utilization of offsite construction methods. Building Research \& Information, 36(1), 56-67. https://doi.org/10.1080/09613210701204013

Pekuri, A., Pekuri, L., \& Haapasalo, H. (2013). The role of business models in finnish construction companies. Australasian Journal of Construction Economics and Building, 13(3), 13-23. https://doi.org/10.5130/ajceb.v13i3.3402

Pekuri, A., Suvanto, M., Haapasalo, H., \& Pekuri, L. (2013). Managing value creation: the 
business model approach in construction. International Journal of Business Innovation and Research, 8(1), 36-51. https://doi.org/10.1504/IJBIR.2014.058045

Polat, G. (2008). Factors Affecting the Use of Precast Concrete Systems in the United States. Journal of Construction Engineering and Management, 134(3), 169-178. https://doi.org/10.1061/(ASCE)0733-9364(2008)134:3(169)

Qi, G. Y., Shen, L. Y., Zeng, S. X., \& Jorge, O. J. (2010). The drivers for contractors' green innovation: An industry perspective. Journal of Cleaner Production, 18(14), 1358-1365. https://doi.org/10.1016/j.jclepro.2010.04.017

Rashid, M. N. A., Abdullah, M. R., \& Ismail, D. (2019). Critical Success Factors CSFs to Automation and Robotics in Industrialized Building System IBS. International Journal of Academic Research in Business and Social Sciences, 8(12), 2207-2221. https://doi.org/10.6007/IJARBSS/v8-i12/5432

Rashid, M. N. A., Abdullah, M. R., Ismail, D., \& Saberi, M. H. (2019). Automation and Robotics in Industrialized Building System (IBS): The Potential Criteria for Measurement. International Journal of Academic Research in Business and Social Sciences, 9(7), 10201034. https://doi.org/10.6007/IJARBSS/v9-i7/6201

Samari, M., Ghodroti, N., \& Shafiei, M. W. M. (2012). The Implementation of Industrialized Building System (IBS) in Iran Construction Companies. Journal of Mechaninal and Civil Engineering, 1(3), 19-24.

Schoenwitz, M., Naim, M., \& Potter, A. (2012). The nature of choice in mass customized house building. Construction Management and Economics, 30(3), 203-219. https://doi.org/10.1080/01446193.2012.664277

Tan, Y., Shen, L., \& Langston, C. (2012). Competition Environment, Strategy, and Performance in the Hong Kong Construction Industry. Journal of Construction Engineering and Management-Asce, 138(3), 352-360. https://doi.org/10.1061/(ASCE)CO.19437862.0000407

Tatum, C. B., Vanegas, J. A., \& Williams, J. M. (1986). Constructability improvement using prefabrication, pre-assembly andmodularization. Stanford University: California, Technical report.

Theong, M. C., Rashid, R. A., \& Chai, C. (2018). Implication of Industrialised Building System (IBS) : The Case of Trade Contractors in Malaysia. International Journal of Engineering \& Technology, 7(2.29), 766-771.

Thuesen, C., \& Hvam, L. (2013). Rethinking the Business Model in Construction by the Use of Off-Site System Deliverance: Case of the Shaft Project. Journal of Architectural Engineering, 19(4), 279-287. https://doi.org/10.1061/(ASCE)AE.1943-5568.0000095

Uusitalo, P., Stehn, L., Brege, S., \& Wernicke, B. (2017). Reciprocal dynamic effectiveness for industrialized house builder. European Operations Management Association Conference 2017, EurOma 2017, Edinburgh, Scotland, July 1-5, 2017.

Xue, H., Zhang, S., Su, Y., \& Wu, Z. (2017). Factors affecting the capital cost of prefabricationA case study of China. Sustainability (Switzerland), 9(9), 1-22. https://doi.org/10.3390/su9091512

Zairul, M. (2017). flexZhouse: New business model for affordable housing in Malaysia (Vol. 7, Issue 2) [PhD Thesis, Delft University of Technology, Netherlands]. https://doi.org/10.7480/abe.2017.2

Zairul, M. (2020). Opening the Pandora Box of Issues in the Industrialized Building System in Malaysia: A Thematic Review. Test Engineering and Management, May-June 2020, 3029-3042. 
Zakaria, S. A., \& El-Abidi, K. M. A. (2020). Economic effects of migrant labor on industrialized building system (IBS) adoption in the Malaysian construction industry. Architectural Engineering and Design Management, $0(0), 1-17$. https://doi.org/10.1080/17452007.2020.1781587

Zakaria, S. A. S., Gajendran, T., Skitmore, M., \& Brewer, G. (2017). Key factors influencing the decision to adopt industrialised building systems technology in the Malaysian construction industry: an inter-project perspective. Architectural Engineering and Design Management, 2007(April), 1-19. https://doi.org/10.1080/17452007.2017.1298512

Zhang, W., Lee, M. W., Jaillon, L., \& Poon, C. S. (2018). The hindrance to using prefabrication in Hong Kong's building industry. Journal of Cleaner Production, 204(2018), 70-81. https://doi.org/10.1016/j.jclepro.2018.08.190

Zott, C. (2007). Business Model Design and the Performance of Entrepreneurial Firms. Organisation Science, 18(2), 181-199. https://doi.org/10.1287/orsc.1060.0232

Zott, C., \& Amit, R. (2010). Business Model Design : An Activity System Perspective. Long Range Planning, 43(2-3), 216-226. https://doi.org/10.1016/j.Irp.2009.07.004

Zott, C., Amit, R., \& Massa, L. (2011). The business model: Recent developments and future research. Journal of Management, 37(4), 1019-1042.

https://doi.org/10.1177/0149206311406265 